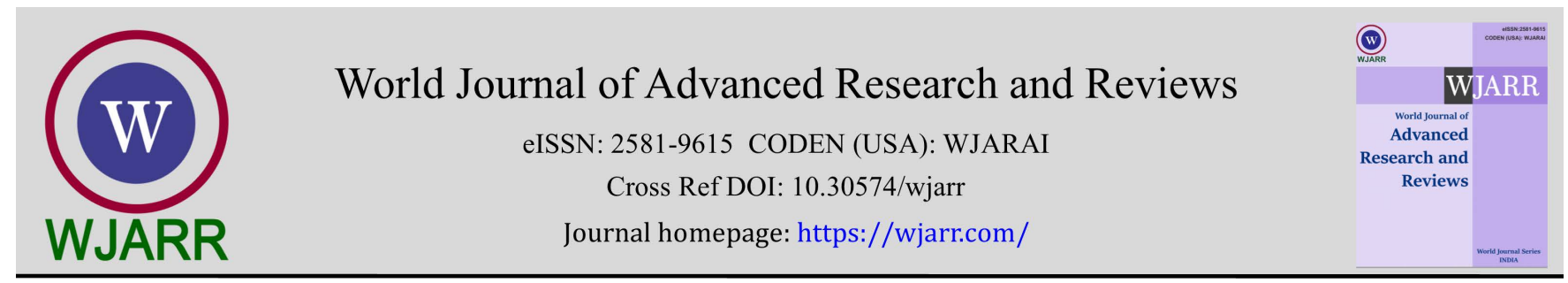

(REVIEW ARTICLE)

Check for updates

\title{
Opportunities in Nigerian cashew nut value chain
}

Kehinde Ademola, Adesanya ${ }^{1,}{ }^{,}$, Mutiat Oluwaseyi Agboola-Adedoja ${ }^{2}$, Adejoke Adebusola Adelusi ${ }^{3}$, Qudus Adebayo Ogunwolu ${ }^{4}$, Chinweike Abednego Ugwu 5, Modinat Adewunmi Alli ${ }^{6}$ and Ayodele Oladipo Akinpelu ${ }^{7}$

Department of Economics and Extension, Cocoa Research Institute of Nigeria, P.M.B. 5244, Ibadan, Oyo State, Nigeria 1234567.

World Journal of Advanced Research and Reviews, 2021, 09(01), 168-174

Publication history: Received on 03 January 2021; revised on 10 January 2021; accepted on 12 January 2021

Article DOI: https://doi.org/10.30574/wjarr.2021.9.1.0008

\begin{abstract}
The demand for cashew nuts is on the rise compared to other tree nuts due to the increase in consumption and utilization of cashew nut products and by-products, respectively. Data from FAO and Review of past literatures was used and this study evaluated the Nigerian cashew value chain as product moves along the stages. It gives information to intending individuals along the value chain. The activities of the actors in the cashew nut value chain are expected to generate employment opportunities for teeming Nigerian youth.
\end{abstract}

Keywords: Opportunities; Cashew nut; Valuechain; Investors

\section{Introduction}

Cashew (Anacardium occidentale) is a multipurpose crop which is mainly cultivated for the nuts' consumption, medicine and source of income for top producing countries of the world [1] Cashew is a nut tree found in the tropics. It originated from Central Brazil [2]. The tree is estimated to live up to 50 to 60 years and it starts bearing fruits within the third and the fifth year. The return on investment of cashew ranges between 30 to 40 percent within 3-5 years of cultivation [3]; this shows that cashew farming is a profitable business. The average yield of the nuts of a mature cashew tree ranges from $7-11 \mathrm{~kg}$ per annum [4]. The most relevant characteristics of cashew are sizes of the nut, tree height, apple colour, resistance to disease and nut yield [5]. Adeigbe et al [6] suggested that increasing production of cashew should be paramount in Nigeria as the demand for cashew in European confectionary industries is increasing. The farmers should have access to improved varieties with better quality and yield from research institutes in order to benefit from the growing cashew nut industry. Aliyu [7] reported that India, Tanzania and Mozambique introduced G-series cashew which has the potential to increase production to $1000 \mathrm{~kg} / \mathrm{ha}$. The potentials of Nigerian cashew nut value chain have not been fully utilized despite the fact that it is a profitable enterprise. There is need for more research funding in the use of cashew nut product and by-products as it can fetch more income to the nation. This study intends to create awareness on investment potentials of cashew nut processing and products. Data from FAO and Review of past literatures on production, processing, marketing of cashew nut was done to achieve the objective of this study.

\section{Value chains in cashew Production}

Value chain is a set of value-adding activities through which a product passes from the initial production to final delivery to the consumer [8]. The cashew value chain shows how value is added and products are being transformed from the farmer to the final consumer. The main objectives of processing of raw cashew nuts perhaps are to give it more economic value and better acceptability in the export market. Discovering the potential benefits of agricultural export

\footnotetext{
${ }^{*}$ Corresponding author: Kehinde Ademola, Adesanya

Department of Economics and Extension, Cocoa Research Institute of Nigeria, P.M.B. 5244, Ibadan, Oyo State, Nigeria 1234567.

Copyright (C) 2021 Author(s) retain the copyright of this article. This article is published under the terms of the Creative Commons Attribution Liscense 4.0.
} 
development for poverty reduction requires careful analysis of trends in global markets and the policies that will unlock the potential for growth and poverty reduction [9].

\subsection{Propagation}

Cashew can be propagated by seed, air layering and softwood graft. Cashew is majorly propagated from seeds in Nigeria. Usually, a good mature large or jumbo size nut is recommended for propagation. A planting spacing of $7.5 \mathrm{~m}$ by $7.5 \mathrm{~m}$, $8 \mathrm{~m}$ by $8 \mathrm{~m}$ and $9 \mathrm{~m}$ by $9 \mathrm{~m}$ with plant population of 175,156 and 123 plants respectively per hectare is recommended for cashew. African cashew alliance [10] reported that 1.8 million tons of raw cashew nut was produced by 3.06million farmers. Cashew farmers spread across Nigeria but the cultivation is prominent in the south and the middle belt region of Nigeria [11].Other management practices to maintain the propagated cashew are mulching, weeding, pruning, pest control, inter-cropping and disease control. Meanwhile, existence of old trees and active deforestation, low yield varieties, high population of small holder farmers are part of problems of cashew production in Nigeria [5].

\subsection{Harvesting}

Judge and Azam-Alli [12] reported that apples are harvested for immediate consumption and juice extraction. The nuts are removed when the ripe fruits drop and during harvesting of the apple. The cashew harvesting is labour intensive and it involves majorly women and children. Post-harvest process is done immediately so as to ensure quality by reducing the moisture content of the raw cashew nut [13]. National Agricultural Extension and Research Liaison Services [11] advised important to ensure that all nuts are properly cleaned of the fleshy parts because cleaned nuts ensure quality and better revenue.

\subsection{Processing}

Post-harvest processing is done immediately after harvesting so as to ensure quality by reducing the moisture content of the raw cashew nut [13].The main processing involves the extraction of the kernel from the shell. The raw cashew nut consists of 50 percent shell, 20-25 percent cashew nut shell liquid (CSNL) contained in the shell and 25 - 30 percent kernel including the testa [15]. The processing of cashew nut products and by-products provide opportunities for value addition and diversification of income of producers and processors. The main objectives of processing of raw cashew nut are to give it more economic value and better acceptability in the export market [13].

\subsection{Marketing}

Marketing is one of the vital activities in the value chain and it extends to the final consumer. The cashew farmers usually supply the nut to rural markets or sell at farm gate. The middlemen or the local buying agents buy in urban market and in turn supply big companies or cooperative buyers that export to international markets. The acceptable standard for cashew nut in the international market involves; cashew nut being of large size and dried to below 8.5 percent moisture content, the nuts must also be matured and pest free [16].

\section{Global cashew nut}

Latest trend in cashew nut shows a global growth rate of 7-10\% annually [17] and it is projected to reach 730,000 metric tons and projected demand by 2023 /2024 is estimated to reach 4,500,000 metric tons. The main consuming countries are India, United States of America, Countries of European Union, China and Middle East. Africa is responsible for 55 percent of world cashew nut production while India and Vietnam are the top cashew processing countries [10].Vietnam has recently introduced new technologies, thus becoming highly competitive against African producers [18]. Nowadays, consumers regard nuts as a healthy snack option. Besides, cashew nuts are well-placed in terms of price as compared to other tree nuts for a variety of reasons ranging from increase in consumption patterns to economic growth in developed countries. The consumption of cashew kernels is projected to continue to grow at increasing rate, providing great opportunities for existing and new investors into the cashew processing sector [17]. Certain factors may be attributed to the recent trend some of which are; use of improved planting materials, better yield, higher reward for farmers, better application of recommended good agricultural practices (GAP) and increasing cashew cultivation areas [19].

\section{Trends in Nigerian cashew nut Production}

Data from Food and Agriculture Organization [20] ranked Nigeria second among the top ten producers of cashew nut in the world with 675,266 tons. However, from 2010, there has been a decline with the latest volume of production of 100,000 tons in 2019 despite the increase in world production. Agada and Sule [21] reported that a ton of Nigerian 
cashew nuts in the world market was sold for N24,753.00 in 1993 and overtime rose to N180,011.00 in 2003. The current price of cashew is N552,757.24 per ton according to [22]. Table 1 below shows that in volume of Nigerian agricultural export of 2018, cashew nut ranked $5^{\text {th }}$.

Table 1 Trend in Nigerian cashew production from 2008-2019.

\begin{tabular}{|l|l|l|}
\hline Year & Production value (tons) & Ranking \\
\hline 2008 & 675,266 & $1^{\text {st }}$ \\
\hline 2009 & 8000,000 & $1^{\text {st }}$ \\
\hline 2010 & 791,721 & $1^{\text {st }}$ \\
\hline 2011 & 562,572 & $2^{\text {nd }}$ \\
\hline 2012 & 412,755 & $3^{\text {rd }}$ \\
\hline 2013 & 192,660 & $5^{\text {th }}$ \\
\hline 2014 & 99,010 & $11^{\text {th }}$ \\
\hline 2015 & 97,149 & $11^{\text {th }}$ \\
\hline 2016 & 98,291 & $11^{\text {th }}$ \\
\hline 2017 & 100,000 & $14^{\text {th }}$ \\
\hline 2018 & 100,000 & $15^{\text {th }}$ \\
\hline 2019 & 100,000 & $14^{\text {th }}$ \\
\hline
\end{tabular}

Table 2 Nigerian Agricultural export of 2018

\begin{tabular}{|l|l|l|}
\hline Item & Value (tons) & Ranking \\
\hline Cocoa, beans & 294,661 & 1 \\
\hline Sesame seeds & 150,000 & 2 \\
\hline Bran, wheat & 129,922 & 3 \\
\hline Cake, palm kernel & 77,000 & 4 \\
\hline Cashew nuts, with shell & 61,867 & 5 \\
\hline Rubber natural dry & 40,773 & 7 \\
\hline Soybeans & 34,587 & 8 \\
\hline Cake, soybeans & 34,553 & 9 \\
\hline Ginger & 31,530 & 10 \\
\hline
\end{tabular}

\subsection{Opportunities in the value chain}

The conceptual framework of the cashew value chain shows the various actors in the value chain and how intending participants can partake and the roles to play in order to further strengthen the value chain. The adaptability of cashew to harsh climatic condition and poor soils provide farmers the opportunities of establishment of new plantations and expansion of old ones. Producers can explore the opportunities in processing by establishing on-farm processing units as a value addition activity which will in turn improve their earnings. Processing of cashew nut focuses on income generation and employment opportunities which can be exploited. Exporters and marketers can explore the opportunities in the growing demand for raw cashew nut in the international markets. Establishment of cashew processing business in Africa will give opportunities to development of a sustainable supply chain with direct business linkage to local farmers, cooperatives and exporters. Studies showed that with worldwide production yield of 1.7 million tons, 450,000 jobs can be created which will result in stable income and better food security [25]. The market has been 
strong for centuries due to the considerable potential of the cashew market for high-value by-products such as CNSL, broken nuts, and cashew shell cake [26]

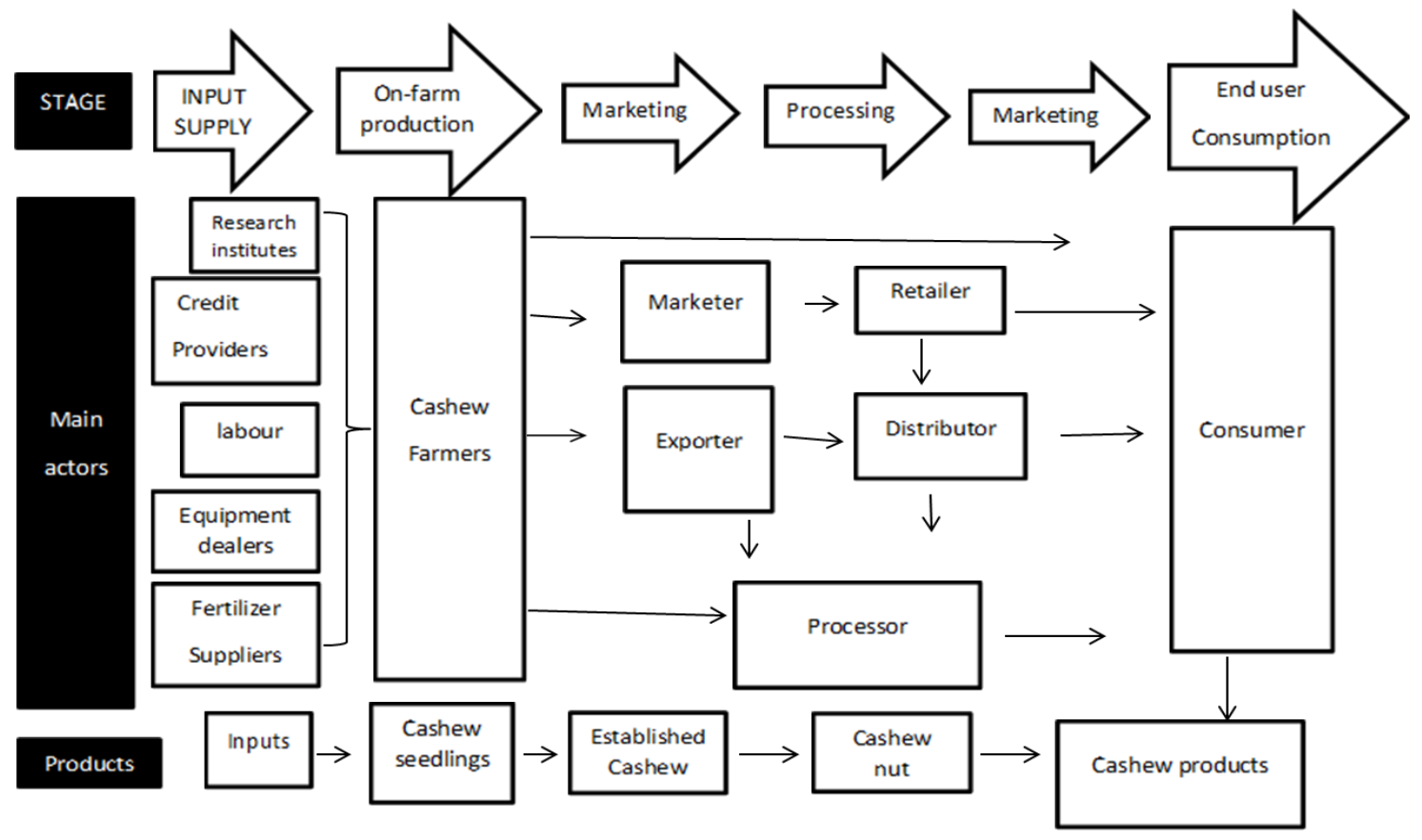

Figure 1 Conceptual framework of cashew value chain Source: Author's concept, 2020.

\subsection{Cashew nut products and by-products}

Cashew nut products and by-products that can be exploited by adding value as listed by Bianca and Stefano [27] are as follows

- Cashew nut kernel is the main production target. It is majorly consumed in form of snack when roasted and salted. Other usage is in the food industries as substitute for other nuts [12]

- Cashew Seedlings: This involves transplanting seedlings from nurseries although it has been reported to have a delicate root system to which transplanting may have a negative impact [12]. However, Abdulsalam and Peter [28] opined that when cashew is propagated by transplanting, seedlings with good tap-roots and lateral roots strive better during transplanting shock and drought.

- $\quad$ CNSL is the top by-product gotten from cashew nut processing because of its unique chemical properties [29]. The 30-35\% of the raw nut shell is the nut shell liquid [30]. The main utilisation of the CNSL is in the polymer sector, where it is the raw materials for brake production, varnishes and surface coating [31].

- Cashew Skin Extract is the reddish brown testa that covers the kernel and it is rich in hydrolysable tannis and polyphenols namely cardol, anacardic acid and cardanol [32].

- Cashew Shell Cake is derived after the removal of the nutshell liquid. The final product is utilized as fuel in cashew nut processing factories and in shell liquid extraction (Nair, 2010). Mohod et al [33] reported that the calorific value is higher than saw dust. Other minor products reported by [2] are cashew kernel oil, cashew kernel powder, cashew kernel butter and cashew kernel milk.

\subsection{Agent, function, products and stages in the value chain}

The various stages in the value chain of cashew as shown in table 3 below describes how the different agents are engaged in the value chain from the production through various marketing and processing channels to the final market. The Nigerian stakeholders include members of African Cashew Alliance (ACA), National Export Promotion Council (NEPC), Small and Medium Enterprises (SMEs), Small and Medium Enterprises Development Agency (SMEDAN). 
Table 2 Function of key actors in the cashew nut value chain

\begin{tabular}{|c|c|c|c|c|}
\hline $\mathbf{S} / \mathbf{N}$ & Stage of chain & Agent & Function ( value addition) & Output \\
\hline 1 & Input supply & $\begin{array}{l}\text { Credit providers, Cocoa research } \\
\text { institute of } \\
\text { researchers), }\end{array}$ & $\begin{array}{l}\text { Marketing, Supply and } \\
\text { transportation. }\end{array}$ & $\begin{array}{l}\text { Inputs delivered, } \\
\text { training and support } \\
\text { services to farmers. }\end{array}$ \\
\hline 2 & $\begin{array}{l}\text { On-farm } \\
\text { production }\end{array}$ & $\begin{array}{l}\text { Farmers, research institutes and } \\
\text { other stakeholders( University) }\end{array}$ & $\begin{array}{l}\text { Establishment, } \\
\text { maintenance, management, } \\
\text { harvesting and selling. }\end{array}$ & $\begin{array}{l}\text { Cashew nuts and } \\
\text { cashew apple }\end{array}$ \\
\hline 3 & $\begin{array}{l}\text { Post-harvest } \\
\text { handling }\end{array}$ & $\begin{array}{l}\text { Farmers research institutes and } \\
\text { other stakeholders( University) }\end{array}$ & $\begin{array}{l}\text { Primary processing (3-day } \\
\text { drying) }\end{array}$ & $\begin{array}{l}\text { Dry cashew nut (low } \\
\text { moisture content) }\end{array}$ \\
\hline 4 & $\begin{array}{l}\text { Post } \\
\text { management } \\
\text { intermediate } \\
\text { trade. }\end{array}$ & $\begin{array}{l}\text { ACA, Licensed buying agents, } \\
\text { Local buying agent, } \\
\text { National association of cashew } \\
\text { Nigeria. }\end{array}$ & $\begin{array}{l}\text { Marketing } \\
\text { transportation. }\end{array}$ & $\begin{array}{l}\text { Graded and sorted } \\
\text { cashew nut to be } \\
\text { exported in good } \\
\text { condition. }\end{array}$ \\
\hline 5 & $\begin{array}{l}\text { Product } \\
\text { transformation }\end{array}$ & Cashew nut Processing firms. & Processing & $\begin{array}{l}\text { Roasted Cashew and } \\
\text { CNSL }\end{array}$ \\
\hline 6 & Export trade & $\begin{array}{l}\text { NEPC, SMEDAN,SMEs, Export } \\
\text { firms and cashew processing firms }\end{array}$ & Export & Cashew nuts \\
\hline 7 & Consumption & Buyers and consumer (end user) & Consumption & $\begin{array}{l}\text { Cashew nut products } \\
\text { and bye-products }\end{array}$ \\
\hline
\end{tabular}

Source: Author's concept, 2020

\section{Conclusion and Recommendation}

The paper examined opportunities in Nigerian cashew nut value chain. It was revealed that cashew production in Nigeria is on the decline, therefore, to scale up production, revitalization of old plantation and establishment of new plantations are recommended. Similarly, given the numerous opportunities identified in the chain, investors are encouraged to harness these opportunities by investing in cashew business as the trend shows that international demand is on the rise. Also, the activities of the actors in the cashew nut value chain are expected to generate employment opportunities for teeming Nigerian youths. Furthermore, a standard cashew nut marketing board is highly recommend to help position Nigeria cashew nut in international markets which will attract more foreign earnings to the country. Thus, Government should motivate more research on cashew nut utilization both in local and international market as it will help strengthen the industry and stimulate production which would help boost the Gross Domestic Product (GDP).

\section{Compliance with ethical standards}

\section{Acknowledgments}

Special thanks to my mentor Dr Ayodele Akinpelu for his guidance and my co-authors for their input toward the success of this paper. I want to also appreciate my wife for her support.

\section{Disclosure of conflict of interest}

The authors declared that there is no conflict of interest.

\section{References}

[1] International Nut and Dried nut Council (INC). Global Cashew Council. Cashew_General Information. International Nut and Dried Fruit Council. 2015. 
[2] Nair KP. The agronomy and economy of important tree crops of the developing world. New Delhi: Elsevier (C). 2010.

[3] Ingredient Sourcing Solution (ISS) État des lieux et Opportunités de la transformation de l'anacarde, presented at SIETTA 2016 ISS (2015); État des lieux et Opportunités de la transformation de l'anacarde, presented at SIETTA. 2016.

[4] Adejo PE, Otitolaye JO, Onuche U. Analysis of marketing channel and pricing system of cashew nuts in North Central Nigeria, Journal of Agricultural Science. 2011; 3(3): 246-248.

[5] Aliyu OM, Hammed LA. Nigerian cashew economy: A review of nut production sector. Paper presented at the International Academy of African Buisiness and Development (IAABD) Conference. University of Florida, Gainesville, USA. 20-24 May 2008.

[6] Adeigbe 00, Olasupo FO, Adewale BD, Muyiwa AA. A review on cashew research and production in Nigeria in the last four decades. Sci. Res. Essays. 2015; 10(5): 196-209.

[7] Aliyu OM. Genetic diversity of Nigerian cashew germplasm. Genetic diversity in plants. $2012 ; 498$.

[8] Kaplinsky R. Spreading the gains from globalisation: what can be learned from value chain analysis? Journal of Development Studies. 2000; 37(2): 117-146.

[9] John H. Global Value Chains in the Agrifood Sector. Institute of Development Studies University of Sussex, Brighton, United Kingdom. 2006.

[10] African Cashew Alliance. Growing cashew industry in focus annual report. 2018.

[11] Olife IC, Jolaso MA, Onwualu AP, Cashew processing for economic development in Nigeria, Agricultural Journal. 2013; 8(1): 45-50.

[12] Judge EC, Azam-Ali SH. Small-scale cashew nut processing. FAO (C) 2001.

[13] Mohod A, Jain S, PowarAG. Energy option for small scale cashew nut processing in India. Energy Res. 2010; 1(1): 47-50

[14] Cashew Production in Nigeria Extension Bulletin. National Agricultural Extension and Research Liaison Services Ahmadu Bello University, Zaria, Nigeria. 2000; 79.

[15] Sornprom N. Extraction and purification of anacardic acid from cashew nut shell. Master of Engineering (Chemical Engineering), Graduate School, Kasetsart University. 2007; 69.

[16] Adeyemi EA, Hammed LA. Assessment of floatation test as a criterion for germinability of cashew nuts. Proc. Horticultural Society of Nigeria (HORTSON): 2003; 101-102.

[17] Deutsche Gesellschaft für Internationale Zusammenarbeit GmbH (GIZ) / ACi; Fitzpatrick J. Competitiveness of African Cashew Sector; www. comcashew.org: 2010.

[18] Fitzpatrick, J. African Cashew Initiative (GIZ/ACi) summary of the study "Cashew Nut Processing Equipment Study" (C). 2011.

[19] Deutsche Gesellschaft für Internationale Zusammenarbeit GmbH (GIZ) / ACi; Fitzpatrick J. Opportunities and Challenges in Cashew Processing in Africa. 2019.

[20] Food and Agriculture Organization (FA0). Cashew industry and production: C. 2018.

[21] Agada MO, Sule EM. Cashew Nuts Production and Marketing among Farmers in Ugwolawo District, Kogi State, Nigeria International Journal of Research Studies in Agricultural Sciences (IJRSAS). 2020; 6(5).

[22] Trigde. Intelligence cashew Nigeria. Seoul: Trigde;C 2020 (cited 2020 Nov 20). Available from https://www.trigde.com/inteligence/cashew-nut/NG

[23] Food and Agriculture Organization(FAO). Cashew industry and production. 2020.

[24] Food and Agriculture Organization(FAO).Cashew industry and production. 2018.

[25] Deutsche Gesellschaft für Internationale Zusammenarbeit GmbH (GIZ) / ACi; Fitzpatrick J. 2016. Competitiveness of African Cashew Sector; www. comcashew.org

[26] Boillereau N, Adam B. Cashew processing, marketing and consumption in West Africa: current status and opportunities. WATH/Accra technical report No. 22, United States Agency for International Development USAID. 2007. 
[27] Bianca D, Stefano C, Cashew from seed to market: A review, Agronomy for Sustainable Development, Springer Verlag. 2014; 34(4): 753-772.

[28] Abdul Salam M, Peter KV. Cashew, a monograph. Studium Press (India) Pvt. Ltd. 2010.

[29] Quirino RL, Garrison TF, Kessler MR. Matrices from vegetable oils, cashew nut shell liquid, and other relevant systems for biocomposite applications. Green Chem. 2014.

[30] Das P, Sreelatha T, Ganesh A. Bio oil frompyrolysis of cashew nut shell-characterization and related properties. Biomass Bioenergy: 2004; 273: 265-275.

[31] Kumar P, Paramashivappa R, Vithayathil PJ, Subba Rao PV, Srinivasa Rao A Process for isolation of cardanol from technical cashew (Anacardium occidentale L.) nut shell liquid. J Agric Food Chem: 2002; 50(16): 4705-4708.

[32] Kamath, V and Rajini, P S The efficacy of cashew nut (Anacardium occidentale L.) skin extract as a free radical scavenger. Food Chem: 2007; 103(2): 428-433.

[33] Mohod AG, Khandetod YP, Powar AG. Processed cashew shell waste as fuel supplement for heat generation. Energy Sustain Dev: 2008; 12(4): 73-76. 